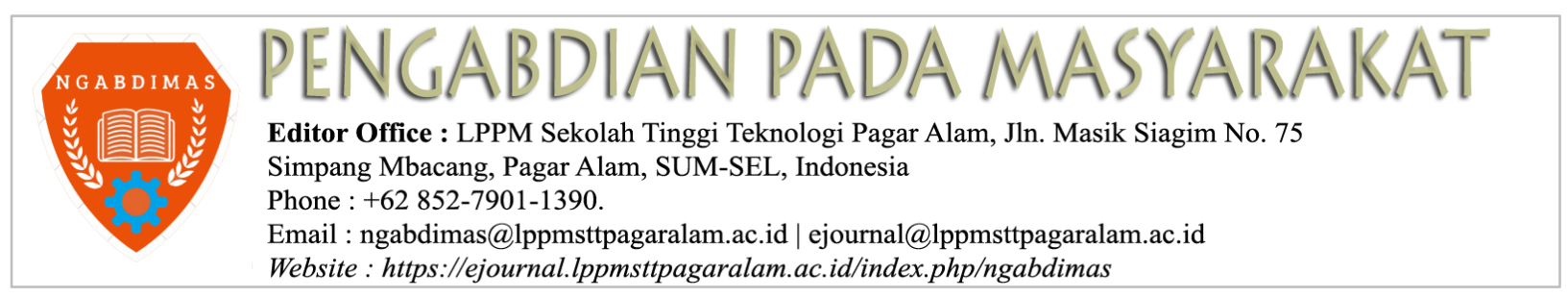

\title{
Pelatihan Pembuatan Blog Pemasaran Dan Penjualan Pupuk Bagi Toko \& Agen Di Jarai
}

\author{
Fitria Rahmadayanti ${ }^{1}$, Desi Puspita ${ }^{2}$ \\ Program Studi Teknik Informatika; Sekolah Tinggi Teknologi Pagaralam (STTP) \\ Jl. M. Siagim No.75 Kel. Karang Dalo, Dempo Tengah, Kota Pagar Alam \\ Telp/Fax: (0730) 621916 \\ e-mail: ria.ria.rr71@gmail.com¹, desiofira1@gmail.com².
}

\begin{abstract}
Abstrak
Pemasaran produk memerlukan teknik atau cara yang baik dan siapa target pasar yang dituju harus dianalisis sedemikian rupa sehingga informasi tentang produk dapat sampai dengan benar, ini memerlukan sarana-sarana yang khusus dan benar sesuai dengan kebutuhan atau sarana yang mudah diakses oleh calon konsumen, perhimpunan toko dan agen pupuk di sekitar Jarai sangat menyadari promosi produk jualannya tidak bisa dilakukan terus menerus dengan cara konvensional perlu ada perubahan dan metode baru, saat ini petani mencari informasi segala hal dengan menggunakan gawai modern dapat dilakukan dimana saja pada saat apa saja hal ini sangat memudahkan sehingga atas kesadaran ini maka perhimpunan toko dan agen se-Jarai merasa perlu belajar melakukan pemasaran menggunakan website (blog), pelatihan menggunakan metode ceramah dan praktek secara langsung, agar pelatihan pembuatan blog pemasaran berjalan sesuai yang diinginkan maka dilakukan observasi hasilnya peserta belum paham sama sekali tentang website (blogging), sehingga pembelajaran harus dilakukan secara pelan-pelan agar peserta paham dan pendampingan saat belajar. Setelah pelatihan dilakukan tes lagi dan hasilnya peserta mampu membuat blog cukup baik, walau pun harus dilakukan pembelajaran lebih lanjut oleh peserta sehingga narasumber memberikan modul belajar agar peserta belajar sendiri setelah pelatihan selesai.
\end{abstract}

Kata kunci-Produk, Konsumen, Metode, Pemasaran, Blog, Modul.

\section{PENDAHULUAN.}

Pengaruh Teknologi informasi dan komunikasi (TIK) khususnya internet saat ini sangat memperngaruhi gaya hidup manusia, salah satunya adalah Blog yang merupakan salah satu fasilitas dari pemanfaatan internet. Media ini sangat banyak sekali digunakan di setiap bidang kehidupan. Tak luput salah satu bidang untuk marketing atau lebih dikenal dengan penjualan serta pemasaran, baik itu bersifat pribadi maupun institusi, Blog (Web Log) merupakan sarana untuk menyimpan informasi secara online yang dapat digunakan oleh siapa saja, dapat memberikan semua informasi tanpa batas ruang dan waktu. Blog atau Web Log adalah catatan pribadi yang dapat ditulis di internet, berisi berupa informasi dan sering di update oleh penggunanya secara kronologis (menurut waktu) blog bisa dikatakan sebagai buku harian.Namun blog perbedaannya blog dapat dibaca oleh siapa saja, tulisan blog dapat berupa fokus pada satu bidang informasi saja, misal seperti politik, budaya, teknologi, olah raga, pendidikan dan lain-lain.namun blog juga bisa berupa jurnal pribadi yang berisi tentang kisah seseorang yang mempunyai blog tersebut pada kehidupan sehari-harinya. Pada bidang pemasaran terbukti pemasaran menggunakan blog memiliki prosfek yang sangat bagus terbukti dengan banyaknya perusahaan-perusahaan penjualan besar yang membuka kesempatan kepada pemilik blog untuk melakukan affiliate marketing, dan terbukti banyak blogger dengan teknik paper klik banyak yang sukses dan benar-benar menghasilkan duit, menyadari kelebihan dari blog ini maka perhimpunan penjual agen dan toko pupuk se-wilayah jarai memandang blog sebagai sarana penting, sehingga dengan menggandeng civitas akademika STTP yang sedang melaksanakan pengabdian di Jarai mengadakan pelatihan pembuatan blog penjualan dan pemasaran bagi seluruh anggotanya, bagi civitas akademika STTP ini menjadi kesempatan dan lahan untuk berbagi. 


\section{METODE.}

Pengabdian dilakukan secara mandiri, tetapi masuk dalam program kegiatan pengabdian perode berlangsung, metodenya dengan seminar dan praktek, pemaparan materi teori masih diperlukan untuk mendahului agar pamahaman peserta pelatihan lebih baik, caranya dilakukan dengan menonton dan menyimak tutorial yang disampaikan narasumber.

\subsection{Pengabdian Pada Masyarakat (PkM).}

Pengabdian secara bahasa diartikan sebagai kegiatan yang memiliki tujuan membantu masyarakat dalam aktivitasnya tanpa mengharap imbalan, biasanya pengabdian dilakukan oleh civitas perguruan tinggi, dilakukan karena sudah termasuk dalam Tri Dharma Perguruan Tinggi yang mana kegiatan yang dilakukan berupa: bakti sosial, mengajar dan sebagainya. Tujuannya antara lain:

1. Meningkatkan inovasi teknologi pada berbagai bidang untuk mendorong pembangunan ekonomi dengan melakukan komersialisasi hasil penelitian;

2. Menyampaikan solusi berdasarkan kajian akademik atas kebutuhan, tantangan, atau persoalan yang dihadapi masyarakat, baik secara langsung maupun tidak langsung;

3. Melaksanakan kegiatan mengentaskan masyarakat tersisih (preferential option for the poor) pada semua strata, yaitu masyarakat yang tersisih secara ekonomi, politik, sosial, dan budaya;

4. Melaksanakan alih teknologi, ilmu dan seni kepada masyarakat untuk pengembangan martabat manusia dan kelestarian sumber daya alam.

\subsection{Internet}

Internet, kependekan interconection and networking, adalah jaringan informasi global, yaitu, "the largest global network of computers, that enables people throughout the world to connect with each other". Internet diluncurkan pertama kali oleh J.C.R. Licklider dari MIT (Massachusetts Institute Technology) pada bulan Agustus 1962. Pemanfaatan internet sebagai media pembelajaran mengkondisikan siswa untuk belajar secara mandiri. "Through independent study, students become doers, as well as thinkers" (Cobine, 1997). Para siswa bisa mengakses secara online berbagai perpustakaan, museum, database, dan mendapatkan sumber primer tentang berbagai peristiwa sejarah, biografi, rekaman, laporan, data statistik, (Gordin et. al., 1995). Informasi diberikan server-computers bisa berasal dari commercial businesses (.com), goverment services (.gov), nonprofit organizations (.org), educational institutions (.edu), atau artistic and cultural groups (.arts)

Siswa bisa berperan sebagai seorang peneliti, menjadi seorang analis, tidak hanya konsumen informasi saja. Mereka menganalisis informasi yang relevan dengan pembelajaran dan melakukan pencarian yang sesuai dengan kehidupan nyatanya (real life). Siswa dan guru tidak perlu hadir secara fisik dikelas (classroom meeting), siswa bisa mempelajari bahan ajar dan mengerjakan tugas pembelajaran serta ujian dengan mengakses jaringan komputer yang telah ditetapkan secara online. Siswa dapat belajar bekerjasama (collaborative) satu sama lain. Mereka dapat saling berkirim $e$ mail (electronic mail) untuk mendiskusikan bahan ajar. Selain mengerjakan tugas pembelajaran dan menjawab pertanyaan dari guru siswa bisa berkomunikasi dengan teman sekelasnya.

Setelah bahan pembelajaran elektronik dikemas dan dimasukkan ke dalam jaringan sehingga bisa diakses melalui internet, kegiatan berikutnya yang perlu dilakukan tentu mensosialisasikan ketersediaan program pembelajaran tersebut agar bisa diketahui masyarakat luas khususnya para peserta didik. Para guru juga perlu diberikan pelatihan terlebih dahulu agar mereka mampu mengelola secara baik penyelenggaraan kegiatan pembelajaran basis intenet. Karakteristik/potensi internet sebagaimana yang telah diuraikan di atas tentunya masih bisa diperkaya lagi dengan yang lainnya. Namun, setidak-tidaknya ketiga karakteristik/potensi internet tersebut dipandang sudah memadai sebagai dasar pertimbangan penyelenggaraan kegiatan pembelajaran melalui internet.

\subsection{Blogging.}

Di era serba modern, serba digital ini, hampir setiap pengguna internet pasti membicarakan mengenai Blog. Istilah Weblog yang kemudian disingkat menjadi Blog sebenarnya mulai dikenal sejak tahun 1997, populer pada tahun 2000an. Blog bentuk aplikasi web yang menyerupai tulisantulisan (posting-an) pada sebuah halaman web umum. Tulisan-tulisan ini sering dimuat pada urut 
terbalik, meskipun tidak selamanya demikian. Saat ini, Blog sudah menjadi bagian tak terpisahkan dari WWW dan dunia per-internet-an. Blog mulai dijadikan sebagai sumber berita koran, majalah, radio, bahkan televisi juga sudah menyiarkan berita lewat Blog. Dunia pendidikan pun sudah banyak menampilkan materi pendidikan dalam Blog yang telah dibuat khusus maupun tidak khusus untuk dunia pendidikan. Pada Blog para pengajar maupun pihak yang berkecimpung dalam dunia pendidikan mem-posting materi yang mereka anggap berguna bagi para pencari informasi pendidikan. Sedangkan pencari informasi pendidikan pun dapat berpartisipasi mengembangkan maupun sekedar memberikan komentar dari isi Blog yang telah dilihat.

\section{Sejarah Blog.}

Pada masa lalu, dunia website memiliki tampilan sederhana, warna background tidak menarik, teks warna hitam dan link berwarna biru. Kemudian berangsur-angsur muncul gambar, suara, animasi, dan video membuat tampilan website menarik. Walaupun demikian, tampilan website masih terlihat statis. Walau ada pendekatan untuk memisahkan data dengan tampilan website dengan cara menyimpan data ke database, tetap saja tampilan berubah jika ada yang meng-update-nya secara manual. Tahun 1990-an mulai muncul software untuk membuat Blog dan muncul juga layananlayanan lain yang mmbuat orang mudah membuat website dan meng-update-nya secara kontinyu. Fasilitas ini mulai berevolusi hingga menjadi layanan Blog seperti sekarang ini. Dengan menggunakan fasilitas blogging, seseorang tidak perlu melakukan koding HTML secara manual untuk menentukan letak isi artikel. Pengguna hanya perlu mengisikan isi artikel ke sebuah form dan menyimpannya, maka isi artikel tersebut otomatis akan ditampilkan software blogging. Dengan dimikian, proses penggantian konten website menjadi lebih mudah, cepat, dan tidak mahal. Media blog pertama kali dipopulerkan Blogger.com, dimiliki PyraLab sebelum akhirnya PyraLab diakuisi Google.Com akhir tahun 2002. Semenjak itu, banyak terdapat aplikasi yang bersifat sumber terbuka yang diperuntukkan kepada perkembangan para penulis blog tersebut. Blog mempunyai fungsi yang sangat beragam,dari sebuah catatan harian, media publikasi dalam sebuah kampanye politik, sampai dengan program media dan perusahaan. Sebagian blog dipelihara seorang penulis tunggal, sementara sebagian lainnya beberapa penulis. Banyak weblog yang memiliki fasilitas interaksi dengan para pengunjungnya, seperti menggunakan buku tamu dan kolom komentar bisa memperkenankan para pengunjungnya untuk meninggalkan komentar atas isi dari tulisan yang dipublikasikan, namun demikian ada juga yang sebaliknya atau yang bersifat noninteraktif. Situs-situs website yang saling berkaitan berkat weblog, atau secara total merupakan kumpulan weblog disebut blogosphere. Bilamana sebuah kumpulan gelombang aktivitas, informasi dan opini yang sangat besar berulang kali muncul untuk beberapa subyek atau sangat kontroversial terjadi dalam blogosphere, maka hal itu sering disebut sebagai blogstorm atau badai blog.

\section{Jenis-jenis Blog}

1. Blog politik: Tentang berita, politik, aktivis, dan semua persoalan berbasis blog.

2. Blog pribadi: Disebut juga buku harian online yang berisikan tentang pengalaman keseharian seseorang, keluhan, puisi atau syair, gagasan jahat, dan perbincangan teman.

3. Blog bertopik: Blog yang membahas tentang sesuatu, dan fokus pada bahasan tertentu.

4. Blog kesehatan: Lebih spesifik tentang kesehatan. Blog kesehatan kebanyakan berisi tentang keluhan pasien, berita kesehatan terbaru, keterangan-ketarangan tentang kesehatan, dll.

5. Blog sastra: Lebih dikenal sebagai litblog (Literary blog).

6. Blog perjalanan: Fokus pada bahasan cerita perjalanan yang menceritakan keteranganketerangan tentang perjalanan/traveling.

7. Blog riset: Persoalan tentang akademis seperti berita riset terbaru.

8. Blog hukum: Persoalan tentang hukum atau urusan hukum; disebut juga dengan blawgs.

9. Blog media: Berfokus pada bahasan kebohongan atau ketidakkonsistensi media massa; biasanya hanya untuk koran atau jaringan televise.

10. Blog agama: Membahas tentang agama.

11. Blog pendidikan: Biasanya ditulis oleh pelajar atau guru.

12. Blog kebersamaan: Topik lebih spesifik ditulis oleh kelompok tertentu.

13. Blog petunjuk (directory): Berisi ratusan link halaman website.

14. Blog bisnis: Digunakan pegawai atau wirausahawan untuk kegiatan promosi bisnis mereka. 
15. Blog pengejawantahan: Fokus tentang objek diluar manusia; seperti anjing.

16. Blog pengganggu: Digunakan untuk promosi bisnis affiliate; juga dikenal sebagai splogs.

\subsection{Pemanfaatan Blog Sebagai Sumber Belajar.}

a. Pengertian Pemanfaatan

Pada kehidupan sehari-hari manusia tidak dapat terlepas dari kata belajar, baik itu belajar dalam lingkungan formal maupun belajar di lingkungan non-formal. Saat manusia belajar sesuatu maka mereka secara sadar maupun tidak sadar telah memanfaatkan sumber belajar yang ada berupa buku, tv, radio, manusia, bahkan internet. Ada lima aspek dalam pemanfaatan, yaitu:

a. Media sebagai teknologi mesin

b. Media sebagai tutor

c. Media sebagai pemotivasi belajar

d. Media sebagai alat berpikir dan memecahkan masalah.

\section{b. Pengertian Sumber Belajar}

Sumber belajar merupakan apa saja (orang, bahan, alat, teknik, lingkungan) yang mendukung serta memungkinkan memberikan kemudahan \& kelancaran belajar, serta memungkinkan terjadinya interaksi antara pebelajar dengan sumber belajar tersebut. Sumber belajar dapat dikelompokan menjadi dua bagian, yaitu :

- Sumber belajar yang sengaja direncanakan (learning resources by design).

- Sumber belajar yang karena dimanfaatkan (learning resources by utilization).

Media massa merupakan suatu jenis komunikasi ditujukan pada sejumlah khalayak yang tersebar, heterogen, dan anonim melewati media cetak atau elektronik, sehingga pesan informasi yang sama dapat diterima secara serentak dan sesaat. Pengertian "dapat" di sini menekankan pada pengertian, bahwa jumlah sebenarnya penerima pesan informasi melalui media massa pada saat tertentu tidaklah esensial. Adapun bentuk media massa, secara garis besar, ada dua jenis, yaitu : media cetak dan media elektronik Agar bisa terjadi kegiatan belajar pada si pebelajar, maka pebelajar harus secara aktif melakukan interaksi dengan berbagai sumber belajar. Perubahan perilaku sebagai hasil belajar hanya mungkin terjadi jika ada interaksi antara pebelajar dengan sumber-sumber belajar. Inilah yang seharusnya diusahakan setiap pebelajar (instructor, pengajar) dalam kegiatan pembelajaran. Oleh karena itu pendidik maupun yang berkompeten dalam hal itu dituntut untuk kreatif menciptakan sumber belajar yang dapat dimanfaatkan oleh pebelajar dalam memahami materi tertentu. Sumber belajar memiliki fungsi :

- Meningkatkan produktivitas pembelajaran dengan: (a) mempercepat laju belajar dan membantu pengajar menggunakan waktu lebih baik dan (b) mengurangi beban pengajar dalam menyajikan informasi, sehingga dapat lebih banyak membina dan mengembangkan gairah.

- Memberikan kemungkinan pembelajaran sifatnya lebih individual, dengan: (a) mengurangi kontrol pengajar kaku dan tradisional; dan (b) memberikan kesempatan bagi pebelajar untuk berkembang sesuai dengan kemampuannnya.

- Memberikan dasar lebih ilmiah terhadap pembelajaran dengan: (a) perancangan program pembelajaran lebih sistematis; (b) pengembangan bahan pengajaran dilandasi oleh penelitian.

- Lebih memantapkan pembelajaran, dengan: (a) meningkatkan kemampuan sumber belajar; (b) penyajian informasi dan bahan secara lebih kongkrit.

- Memungkinkan belajar secara seketika, yaitu: (a) mengurangi kesenjangan antara pembelajaran bersifat verbal dan abstrak dengan realitas sifatnya kongkrit; (b) memberikan pengetahuan yang sifatnya langsung.

- Memungkinkan penyajian pembelajaran yang lebih luas, dengan menyajikan informasi yang mampu menembus batas geografis.

c. Pemanfaatan Blog Sebagai Sumber Belajar

Di dunia semakin modern pemanfaatan teknologi pada pendidikan pun tidak dielakkan lagi. Adanya teknologi modern, arus informasi semakin tak terbendung. Semua orang diseluruh dunia mengetahui apa yang mereka inginkan melalui internet. Internet menghilangkan batas ruang dan waktu sehingga siapa pun dapat memanfaatkanya. Pemanfaatan internet pada pendidikan gencar 
dilakukan diberbagai negara. Bahkan internet menjadi bagian tidak dapat dipisahkan pada pendidikan. Blog salah satu produk yang dihasilkan internet dapat dimanfaatkan sebagai sumber belajar karena $B \log$ dapat dibuat dengan mudah dan gratis.

Fakta penggunaan internet pada pebelajar, lebih banyak dimanfaatkan untuk melakukan hal yang kurang produktif, seperti chatting, friendster-an, game online dan mengakses pornografi. Blog yang jumlahnya berlipat 2 setiap 6 bulan, pemiliknya dari kalangan pebelajar dan remaja sangat signifikan, hal ini merupakan fenomena yang harus dimanfaatkan untuk meningkatkan kualitas pendidikan yaitu dengan membuat Blog yang berkualitas agar masyarakat pebelajar dapat mudah memperoleh informasi. Selain berkualitas, Blog yang dibuat harus menarik agar pebelajar makin betah belajar. Berbagai referensi, jurnal, maupun hasil penelitian dapat dengan mudah di download diberbagai Blog. Cukup memanfaatkan search engine, materi dibutuhkan dapat diperoleh cepat. Selain menghemat tenaga dan biaya dalam mencarinya, materi yang dapat ditemui cenderung lebih up to date. Adapun manfaat Blog bagi pebelajar adalah:

- Dapat meningkatkan pengetahuan,

- Bisa berbagi sumber diantara rekan sejawat,

- Bisa bekerjasama dengan pengajar di luar negeri,

- Ada Kesempatan mempublikasikan informasi secara langsung,

- Bisa untuk mengatur komunikasi secara teratur, dan

- Bisa berpartisipasi dalam forum-forum lokal maupun internasional.

Para pengajar juga bisa memanfaatkan Blog sebagai sumber bahan mengajar dengan mengakses rencana pembelajaran atau silabus online dengan metodologi baru, mengakses materi pembelajaran yang cocok untuk pebelajarnya, serta bisa menyampaikan idenya. Sementara itu pebelajar juga dapat menggunakan internet untuk belajar sendiri secara cepat, sehingga meningkatkan dan memperluas pengetahuan, belajar berinteraksi, dan mengembangkan kemampuan dibidang penelitian. Blog juga dapat dimanfaatkan guru untuk media pembelajaran, yaitu Blog guru sebagai pusat pembelajaran. Guru menuliskan materi belajar, tugas, maupun bahan diskusi di blognya, kemudian murid bisa berdiskusi dan belajar bersama di blog guru tersebut. Selain itu blog guru dan murid dapat saling berinteraksi. Guru, harus memiliki Blog, mengharuskan murid memiliki blog masing-masing, sebagai sarana mengerjakan tugas yang diberikan guru. Metode ini bisa memacu iklim kompetisi antar siswa, karena tentu para siswa ingin blognya menjadi yang terbaik. Setelah semua siswa memiliki Blog dibuat suatu komunitas blogger pebelajar. Ada sebuah Blog sebagai pusat pembelajaran (bisa berupa blog aggregator atau blog beberapa kontributor), dengan guruguru dan siswa dari berbagai sekolah bisa tergabung dalam komunitas blogger pebelajar tersebut.

\section{Conventional Learning dan e-Learning}

Perkembangan TIK diatas, menyebabkan ada perubahan metode konvensional diganti metode e-learning. Metode conventional learning yang mengharuskan pengajar dan pebelajar harus bertatap muka langsung di ruangan memiliki beberapa ciri, yaitu: 1) pembelajaran tergantung pada pengajar; 2) seluruh kegiatan belajar mengajar terpusat di dalam ruang; 3) pengajar merupakan sumber ilmu; 4) dibatasi jarak, ruang dan waktu; dan 5) harus memiliki sarana dan prasarana belajar mengajar yang memadai serta sumber daya manusia pengajaar yang memahami setiap materi pembelajaran yang akan diajarkan. Sedangkan ciri-ciri e-learning adalah: 1) pembelajaran tidak tergantung kepada pengajar; 2) banyaknya sumber materi dan kemudahan akses; 3) peran pengajar hanya sebagai mediator atau pembimbing; 4) proses belajar tidak terkendala jarak, ruang dan waktu. Merujuk dari ciri-ciri kedua metode di atas, maka nge-blog adalah sebuah alternatif metode proses belajar mengajar yang bersifat e-learning dan juga student centered. Penyelenggara pendidikan seperti Perguruan tinggi yang ingin menggunakan Teknologi Iinformasi dan Komunikasi untuk penerapan e-learning biasanya menggunakan Learning Management System (LMS) untuk menyediakan virtual classroom (ruang kelas virtual) di internet. Virtual classroom yang dimiliki biasanya memiliki banyak metafora ruang kelas konvensional seperti forum diskusi, pengumpulan tugas, katalog/perpustakaan bahan ajar, katalog hyperlink dan lain sebagainya. 


\subsection{Pre \& Pos Tes.}

Pre Test yaitu suatu bentuk pertanyaan, yang dilontarkan guru kepada muridnya sebelum memulai suatu pelajaran. Pertanyaan yang ditanya adalah materi yang akan diajar pada hari itu (materi baru). Pertanyaan itu biasanya dilakukan guru di awal pembukaan pelajaran. Pre test diberikan dengan maksud untuk mengetahui apakah ada diantara murid yang sudah mengetahui mengenai materi yang akan diajarkan. Pre test juga bisa di artikan sebagai kegiatan menguji tingkatan pengetahuan siswa terhadap materi yang akan disampaikan, kegiatan pre test dilakukan sebelum kegiatan pengajaran diberikan. Adapun manfaat dari diadakannya pree test adalah untuk mengetahui kemampuan awal siswa mengenai pelajaran yang disampaikan. Dengan mengetahui kemampuan awal siswa ini, guru akan dapat menentukan cara penyampaian pelajaran yang akan di tempuhnya nanti.

Post test merupakan bentuk pertanyaan yang diberikan setelah pelajaran/materi telah disampaikan. Singkatnya, post test adalah evalausi akhir saat materi yang di ajarkan pada hari itu telah diberikan yang mana seorang guru memberikan post test dengan maksud apakah murid sudah mengerti dan memahami mengenai materi yang baru saja diberikan pada hari itu. Manfaat dari diadakannya post test ini adalah untuk memperoleh gambaran tentang kemampuan yang dicapai setelah berakhirnya penyampaian pelajaran. Hasil post test ini dibandingkan dengan hasil pree test yang telah dilakukan sehingga akan diketahui seberapa jauh efek atau pengaruh dari pengajaran yang telah dilakukan, disamping sekaligus dapat diketahui bagian bagian mana dari bahan pengajaran yang masih belum dipahami oleh sebagian besar siswa.

\subsection{Penyelesaian Masalah.}

Mengadakan pelatihan pembuatan blog, itulah penyelesaian yang bisa dilakukan, sehingga berdasarkan kebutuhan ini maka pelatihan diadakan di Ruang Pertemuan Kecamatan Jarai atas ijin Camat Jarai, menggunakan Laptop peserta pelatihan dan peserta KKN, serta komputer milik kantor Kecamatan jarai, dilaksanakan sehari dengan metode ceramah langsung praktek.

\section{PEMBAHASAN DAN HASIL.}

3.1. Realisasi \& Pemecahan Masalah.

Pengabdian dilaksanakan satu hari di aula kantor Camat Jarai, dihadiri 20 orang peserta pelatihan, yang mana pelatihan diahului dengan acara seremonial pembukaan dilakukan dengan sambutan dan pembukaan pelatihan oleh camat, dilanjutkan dengan pelatihan, dan kesempatan diberikan kepada narasumber untuk menyampaikan materi. Narasumber sebelum menyampaikan materi melakukan tes, berupa pre tes pendahuluan untuk mengetahui pemahaman perserta terhadap teknologi informasi, website (blogging), berikutnya disampai teori tentang teknologi informasi dan blogging terakhir semua peserta berdasarkan teori yang diberikan diminta membuat blog sendiri, maka berikut merupakan langkah-langkah pelaksanaan pengabdian yang sudah dilakukan oleh pengabdi, yang mana pada dilaksanakan secara berurut sebagai berikut:

Tabel 1. Kegiatan

\begin{tabular}{|l|c|l|l|}
\hline Pelaksanaan & Waktu & \multicolumn{1}{|c|}{ Materi } & \multicolumn{1}{|c|}{ Penyaji } \\
\hline \multirow{4}{*}{1 hari } & $08.00-09.00$ & Pre Test & \\
& $09.00-09.30$ & Persiapan Membuat Blog & Fitria \\
\cline { 2 - 4 } & $09.30-12.00$ & $\begin{array}{l}\text { Panduan Membuat Blogdan Tutorial Membuat } \\
\text { Blog dengan Wordpress } \\
\end{array}$ & $\begin{array}{l}\text { Rahmadayanti, } \\
\text { Desi Puspita }\end{array}$ \\
& $12.00-12.30$ & $\begin{array}{l}\text { Ishoma } \\
\text { Post-test }\end{array}$ & \\
\hline
\end{tabular}

Sehingga berdasarkan penjelasan diatas rincian kegiatan menjadi termanajemen dan tertata dengan baik sehingga pelaksanaan berjalan dengan lancar karena kegiatan telah disusun terlebih dahulu sehingga tinggal melaksanakan sesuai urutan yang ada, dan untuk menjaga kualitas kegiatan yang dilakukan ini pada akhir acara dilakukan lagi tes, berupa pos tes terhadap seluruh peserta yang mengikuti pelatihan, pos tes dilakukan oleh narasumber untuk mengetahui seberapa 
efektifnya pelaksanaan pengabdian pelatihan pebuatan blog yang diaplikasikan untuk penjualan ini.

\subsection{Pembahasan \& Hasil.}

Berdasarkan urutan pelaksanaan pengabdian yang dilaksanakan diatas yang terdeskripsi didalam tabel 1. Maka berikut ini merupakan uraian keberhasilan yang didapatkan dari pelaksanaan pengabdian yang dilaksanakan di Aula Kantor Camat Jarai, yang mana pada pelaksanaannya peserta harus diberikan pemahaman bukan hanya aplikasi tetapi pemahaman dasar tentang TI, Website dan blogging yang mendukung dalam melakukan pemasaran atau penjualan pupuk pada wilayah Kec. Jarai.

Tabel 2. Keberhasilan Pelaksanaan Kegiatan

\begin{tabular}{|l|l|}
\hline \multicolumn{1}{|c|}{ Materi } & \multicolumn{1}{|c|}{ Hasil } \\
\hline Pendahuluan & $\begin{array}{l}\text { Pendahuluan kegiatan adalah narasumber melakukan pre tes } \\
\text { terhadap peserta, peserta paham maksud dari pelatihan. }\end{array}$ \\
\hline Pengantar Blogging & $\begin{array}{l}\text { Peserta mengetahui tentang teknologi blogging, yang } \\
\text { diaplikasikan untuk pemasaran. }\end{array}$ \\
\hline Praktek Pembuatan Blog & $\begin{array}{l}\text { Mempraktekan seluruh langkah yang dilakukan atau yang } \\
\text { disampaikan saat teori. }\end{array}$ \\
\hline Penutup & $\begin{array}{l}\text { Narasumber melakukan pos tes untuk mengetahui } \\
\text { pemahaman peserta pelatihan terhadap materi yang } \\
\text { disampaikan. }\end{array}$ \\
\hline
\end{tabular}

Pelatihan membuat website penjualan dan pemasaran yang dilakukan bagi para agen dan pemilik toko pupuk di kecamatan jarai Kab. Lahat, dilakukan satu hari yang dihadiri sebanyak 20 orang peserta pada saat pre tes dilakukan peserta belum memahami blogging, sehingga narasumber harus menjelaskan secara menyeluruh tentang teknologi website, teknologi bloging dan teknis pemasaran dan penjualan melalui website atau blog, sehingga pada penjelasan teori narasumber menjelaskan secara keseluruhan dan memberikan contoh aplikasi yang sudah jadi dari website penjualan ini, selanjutnya setelah peserta paham dengan teori yang disampaikan dilakukan praktek membuat blog dengan bahan data yang dimiliki jadi peserta pelatihan langsung membuat blog untuk tokonya sendiri dengan bimbingan narasumber dan hasilnya mereka mampu membuat blog sesuai langkah modul dan arahan atau bimbingan dari narasumber.

Hasilnya peserta dapat membuat blog sendiri, bahkan sudah bisa merubah-rubah tampilan pada blog-nya sehingga tampilan menjadi lebih menarik, hal ini terlihat dari hasil pos tes, peserta $100 \%$ bisa membuat website sesuai dengan instruksi dan bimbingan dari narasumber, maka keberhasilan dapat diidentifikasi sebagai berikut:

a. Peserta pelatihan mempunyai pengetahuan dan pemahaman yang baik tentang Blogging.

b. Seluruh peserta menjadi sangat paham terhadap teknologi informasi yang lebih aplikatif untuk mendukung dalam pengolahan data penjualan yang up to date.

\section{KESIMPULAN}

Pada pelaksanaan pengabdian masyarakat (PkM) ini yang dilakukan pada Pemilik toko dan agen pupuk dengan tujuan melatih mereka memahami blogging pemasaran produk yang dimilikinya didapatkan kesimpulan sebagai berikut:

a. Melaksanakan proses pembelajaran dengan cara belajar aplikasi secara langsung ternyata sudah mampu meningkatkan semangat belajar menjadi lebih baik (giat), dari peserta pelatihan.

b. Mampu menambah softskills para peserta pelatihan terhadap teknologi informasi khususnya blogging, untuk penjualan.

c. Meningkatkan rasa percaya diri peserta terhadap pemahaman teknologi informasi dengan kemampuannya ketika di masyarakat. 


\section{SARAN}

Maka dari pengalaman yang dilihat dan dirasakan penulis (pengabdi) saat melaksanakan pengabdian ini maka, penulis dalam hal ini bisa memberikan saran:

a. Memberikan waktu pengabdian lebih lama agar peserta pelatihan semakin ahli.

b. Pendanaan pengabdian yang baik.

\section{UCAPAN TERIMA KASIH}

Pengabdi mengucapkan terima kasih kepada Panitia KKN dan Pengabdian bagi Dosen, terima kasih kepada keluarga, kawan-kawan dosen, Camat Jarai, dan sebagainya.

\section{DAFTAR PUSTAKA}

[1] Muslim, B. 2018. Pelatihan aplikasi editing video dengan filmora., Laporan Pengabdian Kepada Masyarakat, LPPM STT Pagaralam.

[2] Michael Simkins, Karen Cole, Fern Tavalin and Barbara Means, Increasing Student Learning Through Multimedia Projects Diakses dari http://www.ascd.org/publications/ books/ 102112/ chapters/ What Is

Based_Multimedia_Learning\%25C2\%25A2.aspx.

[3] Richard E. Mayer, Roxana Moreno, 1998, Aids to computer-based multimedia learning,Richard E. Mayer*, Roxana MorenoDepartemen Psikologi, University of California, Santa Barbara, CA 93106, USA Department of Psychology, University of California, Santa Barbara, CA 93106, USA.

[4] Muslim, B. 2018. Pelatihan Pembuatan Blog Bagi Guru Ma Ponpes Darul Mutaqin Kota Pagaralam. NGABDIMAS. Vol 1. No.1. Bulan Juni, Hal. 6-11

[5] B. Muslim, Pengantar teknologi informasi. Yogyakarta: Deepublish, 2017.

[6] Muslim, B. (2018). Analisis system informasi (SI) terintegrasi di Perguruan Tinggi (PT) (Studi Kasus: STT Pagaralam). Jurnal Teknologi Informasi MURA, Vol 10. Page 83-91.

[7] Muslim, B (2014). Analisis rencana aplikasi teknologi informasi pada STT Pagar Alam. Proseding semnastik dan Magma. Issue: Aplikasi Teknologi dan sistem Informasi. PPP UBD Pres. Pages 397-404.

[8] Hutchinson E. Sarah and Sawyer C. Stacey, 2000, Computers, Communications \& Information, McGraw Hill Companies Inc.

[9] Indonesia Services Education HP Tim, 2001, Manajemen Sistem Belajar Di Dunia Maya, Majalah Info Komputer.M.H Jogiyanto, 1995, Pengenalan Komputer, Andi Offset Yogyakarta.

[10] Horsley, M., Knight, B., \& Huntly, H. 2010. The role of textbooks and other teaching and learning resources in higher education in Australia: Change and continuity in supporting learning. IARTEM 1-Journal. 3(2). 43-61.

[11] Sadiman, A.S., Rahardjo, R., Haryono, A., \& Rahardjito. 2006. Media pendidikan: Pengertian, pengembangan, dan pemanfaatan. Jakarta: Rajagrafindo Persada.

[12] Menristekdikti. 2016. Panduan Pelaksanaan Penelitian dan Pengabdian Masyarakat di Perguruan Tinggi Edisi X Tahun 2016. hlm. 4.

[13] Gilbert, D. (2002). Multimedia Technology, Queensland: University of Queensland.

[14] Eleanor L. Criswell (1989), Design of Computer-Based Instruction, Macmillan Pub Co, 1989.

[15] Unesco, Introduction | The multimedia approach, diakses dari www.unesco.org/ education/tlsf/ TLSF/intro/mod02/uncom, tanggal 1 September.

[16] Suyanto, Analisis dan Desain Aplikasi Multimedia untuk Pemasaran, Andi Offset Yogyakarta 2004.

[17] Isro'Mukti, Y. (2017). Sistem Informasi Madrasah Aliyah Negeri Pagar Alam Berbasis Web. Indonesian Journal of Computer Science, 6(2), 192-205.

[18] Mukti, Y. (2017). Perencanaan Strategis Sistem Informasi Dan Teknologi Informasi Pada Sekolah Menengah Kejuruan Negeri 2 Pagar Alam. JURNAL ILMIAH BETRIK: Besemah Teknologi Informasi dan Komputer, 8(02), 83-92.

[19] Arif, A., \& Mukti, Y. (2017). Rancang Bangun Website Sekolah Menengah Pertama (SMP) Negeri 8 Kota Pagar Alam. JURNAL ILMIAH BETRIK: Besemah Teknologi 
Informasi dan Komputer, 8(03), 156-165.

[20] Isro'Mukti, Y. (2018, October). Sistem Informasi Manajemen Aset Sekolah Tinggi Teknologi Pagaralam Berbasis Web. In Seminar Nasional Teknologi Informasi dan Komunikasi (SEMNASTIK) (Vol. 1, No. 1, pp. 632-638).

[21] Mukti, Y. (2018). Rancang Bangun Website Sekolah Dengan Metode User Centered Design (UCD). JURNAL ILMIAH BETRIK: Besemah Teknologi Informasi dan Komputer, 9(02), 84-95.

[22] Mukti, Y. (2018). Pelatihan Maintance Komputer SMAN Pagar Gunung. NGABDIMAS, $1(1), 47-51$.

[23] Mukti, Y. I. (2019). Implementasi Jaringan Hotspot Kampus Menggunakan Router Mikrotik. Indonesian Journal of Computer Science, 8(2), 130-138.

[24] Mukti, Y. I., \& Puspita, D. (2019). Sistem Informasi Peringatan Dini Bencana Pada Kota Pagar Alam Berbasis Mobile. Jusikom: Jurnal Sistem Komputer Musirawas, 4(2), 65-74.

[25] Mukti, Y. I. (2019). SISTEM INFORMASI MONITORING KESEHATAN MASYARAKAT BERBASIS WEB MENGGUNAKAN METODE UNIFED MODELLING LANGUAGE. Jusikom: Jurnal Sistem Komputer Musirawas, 4(1), 1-8.

[26] Mukti, Y. I., \& Puspita, D. (2019, December). Web Based Disaster Early Warning System on Pagar Alam City. In Conference SENATIK STT Adisutjipto Yogyakarta (Vol. 5, pp. 309-316).

[27] Isro'Mukti, Y., \& Puspita, D. WEB BASED DISASTER EARLY WARNING SYSTEM ON PAGAR ALAM CITY.

[28] Puspita, D., \& Isro'Mukti, Y. (2019, December). Web-Based Culture Information System of Literature Besemah City of Pagar Alam. In Conference SENATIK STT Adisutjipto Yogyakarta (Vol. 5, pp. 303-308). 